\title{
MAL-BRANCO, HUMANISMO, CIVILIZAÇÃO: TENSÕES E PERVERSÕES EM ENSAIO SOBRE A CEGUEIRA, DE JOSÉ SARAMAGO
}

WHITE EVIL, HUMANISM, CIVILIZATION: TENSIONS AND PERVERSIONS IN ENSAIO SOBRE A CEGUEIRA, BY JOSÉ SARAMAGO

Gislene Teixeira Coelho*

RESUMO: Este artigo apoia suas discussões na representação da cegueira branca da obra Ensaio sobre a cegueira, de José Saramago, que visualiza nessa experiência radical a potência de esgarçar os conceitos de civilização e civilidade e de instaurar um mal-estar social, apontando a falência dos principais instrucultura, a religiăo e aciencia. Disculir-se-ào os limites que distintenuidade e a ilitida na from e da babárie, reforçando a tenuide e a llegitimidade das fronteiras que os separam e levantando uma postura crítica em direção à visão arrogante impositiva do homem. Para tanto, Jacques Derrida, na obra $O$ animal que logo sou, encabeça o pensamento crítico que tenta subverter a palavra homem e a razão centralizadora e dominante. Em suma, a ficção de Saramago e os trabalhos teóricos elencados dialogam ao expor um lamento pela desumanizaça críticos de um chamado para que o humanismo seja colocado na agenda do dia.
PALAVRAS-CHAVE:
Cegueira
branca;
Descivilização

gislene.coelho@ifsudestemg.edu.br

Doutora em Letras: Estudos Literários pela Universidade Federal de Juiz de Fora. Professora do Instituto Federal do Sudeste de Minas Gerais (Campus Juiz de Fora - MG)

ABSTRACT: This article supports its discussions on the representation of the white blindness of the work Ensaio sobre a cegueira, by José Saramago, who visualizes in this radical experience the power to damage the concepts of civilization and civility and to establish a social unrest, pointing out the bankruptcy of the main instruments of social control and power, like the army, the government, culture, religion and science. It will be discussed the limits that distinguish human from animal, nature and barbarism reinforcing the fragility and the illegitimacy of the frontiers that separate them and raising a critical attitude towards the human's arrogant and imposing view. For this purpose, Jacques Derrida, in the work $O$ animal que logo sou, heads the critical thinking that tries to subvert the word human and the centralizing and dominant reason. In summary, Saramago's fiction and the selected theoretical works dialog by exposing a regret for the dehumanization of man and hu zation of man and human practices, as well as they leave critical tracks of a call for humanism to be placed on the agenda of the day,

KEYWORDS: White blindness; Decivilization; Dehumanization. 
Freud recupera do poeta-filósofo Schiller uma frase que sintetiza as reações humanas dentro do universo social, que diz: "São a fome e o a mor que movem o mundo". (SCHILLER apud FREUD, 1997, p. 75). Essa curta citação tem o potencial de exprimir o que mais nos perturba ao ler O mal-estar na civilização, a saber, o mal, a maldade, a maldição, a agressividade, a perversão são forças que estão por dentro, na interioridade, na intimidade do homem, de modo que estímulos externos podem mover algo que estava latente, bem perto, bem dentro, provocando (re)ações imprevistas e indesejadas pela civilidade. A fome pode mover (re)ações que colocam à prova os conceitos e práticas bem conhecidos de civilidade e civilização, expulsando de dentro para fora representações do mal, da barbárie e da agressividade, as quais chegam a abafar as manifestações humanas de bondade, civilidade e afeição.

Sintomático do mal-estar freudiano, o romance Ensaio sobre a cegueira, uma publicação de 1995, de José Sara mago, deixa o registro de uma civilização sob ameaça. À primeira vista, a a meaça viria de fora, da cegueira branca que acomete quase toda a população, no entanto, ações e reações humanas cotidianas mostram sua nocividade, expulsando exemplos de maldade e incivilidade A fome, termo muito oportuno para a leitura que ora se propõe, pode ser interpretada como símbolo dos diversos males que assombram e prejudicam o processo de socialização e entendimento humano. Nesse sentido, comumente desperta reações destrutivas e negativas no papel social do homem, que passa a ocupar a posição de confronto e de defesa contra o mundo. A fome, portanto, assombra as páginas do romance, expulsando da intimidade dos homens ações e reações no seu aspecto mais degradante, primitivo e repulsivo.

Sara mago ficcionaliza no romance o cenário de vivência de uma experiência radical e de sobreposição de atos de violência, de forma que os conflitos se acirram no decorrer da narrativa, emergindo instintivamente uma prontidão para a luta e para a competição. A marca da violência é trabalhada como o contraponto emocional que desestabiliza os elos de afetividade e que desafia qualquer tipo de agrupamento humano, dada sua atuação disseminadora de dor, isola mento e sofrimento. Dentre os níveis de violência impregnados em Ensaio sobre a cegueira, destacam-se a violência "diplomática" dos discursos de poder entremeados nos campos da ciência, da cultura e da política, a violência que produz uma série de reações grotescas e cotidianas, violência entre indivíduos e entre grupos, enfim, a violência que expulsa das intimidades de outros tantos homens reações de igual e de maior calibre, congregando ascendentemente mais adeptos. 
Fome e violência provam, em uma primeira leitura do livro de Saramago, a fragilidade do discurso civilizatório e a instabilidade da civilidade do homem e, em um segundo momento, em tom mais lamurioso, testa $\mathrm{m}$ os valores do humanismo e do humanitarismo dos e entre os homens. Nesse sentido, o escritor português orquestra uma leitura que pressiona pela revisão do conceito de humanismo, bastante desgastado e apagado, conforme a nunciam algumas das teorias e dos teóricos pós-modernos, que projetam um quadro trágico de descrença e distopia no próprio homem e em sua humanidade. Em contrapartida, o escritor aborda criticamente o fato de que o conceito de civilização ganha destaque para representar o mundo e seus avanços científicos, seu estado de progresso e seu status cultural, que tornaram o homem ideal (e idealizado) o equivalente ao bem-educado, instruído.

\section{CEGUEIRA, DESCIVILIZAÇÃO, DESASSEPSIA}

O romance Ensaio sobre a cegueira, de José Sa ra mago, permite retomar e atualizar uma instigante discussão em torno da palavra civilização, apresentando sua fragilidade e sua instabilidade diante de uma experiência inaudita: a cegueira branca. Essa experiência radical, que atinge paulatinamente a população de uma cidade, com exceção somente da mulher do médico, testa os limites do homem e de seu entendimento como ser racional civilizado, situação que observa mos através das reações e transformações do grupo humano enclausurado no manicômio, que fazem oscilar o próprio entendimento que temos da palavra homem.

O conceito de civilização sofre um constante processo de revisão no romance, sua força conceitual binária é deslocada a partir do embate com tudo aquilo considerado não-civilizado. Sua formulação parte insistentemente do princípio da negação, sendo, portanto, oposto ao que é bárbaro, inculto, rude, desordenado e grotesco, ou seja, o civilizado afirma-se no confronto com a alteridade. O ideal civilizatório parte do princípio da igualdade e padronização, de modo que, ao suprimir as diferenças, acredita eliminar as possibilidades de conflito e confronto social.

Para a construção da civilidade, a experiência do olhar parece ser fundamental, pois sua formulação conceitual tem sido historica mente perpassada pelo confronto, distinguindo aspectos naturais e culturais, agradáveis e repulsivos, belos e grotescos. Os olhos monitora m o espaço em que vivemos e as escolhas que fazemos, julgando de acordo com modelos determinados socialmente, modelos esses que se encaixam no rótulo de civilizado. Eles podem 
assegurar um elo entre o indivíduo e a humanidade, já que sua experiência se pauta tanto pela negação como pela identificação com as outras pessoas e com o contexto social circundante, situação expressa no fragmento:

[...] aproveitamos o acaso de haver aqui ainda uns olhos lúcidos, os últimos que restam, se um dia eles se apagarem, não quero nem pensar, então o fio que nos une a essa humanidade partir-se-á, será como se estivéssemos a afastar-nos uns dos outros no espaço, para sempre, e tão cegos eles como nós, (SARAMAGO, 1995, p. 290)

Para assegurar a condição ideal de bem-estar, os olhos a tua m como agentes de assepsia e ordenação dos aglomerados humanos. Seu apaga mento - a cegueira coletiva ficcionalizada por Saramago - implica a transformação completa do espaço urbano e de sua civilidade: "[...] o que estava ali não era uma cidade, era uma extensa massa de alcatrão que ao arrefecer se moldara a si mesma em forma de prédios, telhados, chaminés, morto tudo, apagado tudo." (SARAMAGO, 1995, p. 260), de modo que sua ausência instaura o tão temido caos urbano: sujeira, depredação, insegurança, fome e desespero, situações que acompanham a vida dos personagens do romance.

Interessante pensar na escolha de Saramago, pois, ao suprimir um dos nossos sentidos - a visão - , esfacela-se a base organizacional urba na, e, concomitantemente, sugere-se uma relação intrínseca entre civilização e visão. Dentre os sentidos humanos, na vida em sociedade, a visão é supervalorizada tendo em vista sua atuação produtiva no que concerne à ordenação e padronização espaço-social. Esse sentido, em especial, reproduz o ideal civilizacional ao sensibilizar-se diante de imagens que nos causa m distintas reações, como medo, horror, repúdio, vergonha, prazer, contenta mento e segurança.

Os olhos, ao orquestrarem o espaço humano, acompanham o ritmo ditado pelos três princípios básicos de civilidade lembrados por Freud em O mal-estar na civilização: "Evidentemente, a beleza, a limpeza e a ordem ocupam uma posição especial entre as exigências da civilização" (FREUD, 1997, p. 47). Todos esses princípios norteiam a construção das cidades como condição ideal, de modo que tudo o que a meaça esse quadro harmônico deve ser eliminado ou ocultado. A civilização tenta assegurar seu controle a través de uma higienização do espaço, de modo que os dejetos, as doenças, os criminosos, os loucos e outras tantas "ameaças" sejam afastadas, consequentemente, não comprometendo a imagem citadina de beleza, ordenação e segurança. 
Os centros urbanos, principalmente, devem espelhar-se na imagem de um cartão postal, onde o foco está em tudo que divulgue beleza, modernidade e riqueza. As cidades-cartões-postais investem altas quantias para manter sua aparência atrativa e civilizada, o que mostra uma relação estreita entre civilização e poder econômico. Os centros econômicos sempre foram facilmente associados a a mbientes civilizados, pois dispunham de condições financeiras favoráveis para comprar todos os bens culturais ou materia is de que as pessoas necessitassem ou desejassem. O conceito de civilização está fortemente vinculado a instituições de ensino de qualidade, a esquemas de segurança confiáveis, a um planejamento urba nístico moderno, à existência de locais de produção cultural como cinemas, teatros e museus, à construção de centros comerciais bem equipados e modernos, itens que exigem grandes investimentos do poder público e que estão indisponíveis a uma considerável parcela da população que habita as cidades.

Raros são os exemplos de cidades que atingem o ideal civilizacional, pois, além de não oferecer uma infraestrutura desejável, esbarram nos graves problemas sociais que abarrotam as ruas e avenidas de moradores de rua, desempregados, pedintes e dependentes químicos. Essa parcela (considerável) da população perturba o ideal civilizacional de salubridade, beleza e comodidade, logo, são cidadãos indesejáveis. Comumente, diante de qualquer ameaça à estética ou ao bem-estar social, adota-se o afastamento do elemento perturbador, como ocorre com os cemitérios, os presídios, os albergues e os manicômios que estão localizados, em sua grande maioria, em lugares mais distantes dos centros de produção econômica e cultural das cidades.

Em Ensaio sobre a cegueira, a primeira atitude do governo perante a epidemia da cegueira branca é o isolamento dos doentes em um manicômio já desativado, submetendo-os inclusive a um tratamento desumano, a exemplo de antigas práticas como se vê no trecho que diz:

Em palavras ao alcance de toda a gente, do que se tratava era de pôr de quarentena todas aquelas pessoas, segundo a antiga prática, herdada dos tempos de cólera e da febre-amarela quando os barcos conta minados ou só suspeitos de infecção tinham de permanecer ao largo durante quarenta dias, até ver. (SARAMAGO, 1995, p. 45)

O excerto lembra o fato de que os métodos de controle continuam os mesmos, os doentes são levados para o isola mento "até ver", ou seja, até que a doença ou a desassistência do governo os consuma ou, na mais improvável 
das hipóteses, até que surja a cura. Esse tipo de medida visa a controlar a a meaça branca em nome da "segurança nacional", tendo em vista o estado de horror que se instaura diante do medo da epidemia.

\section{CEGUEIRA, DESCIVILIZAÇÃO, FALÊNCIA NACIONAL}

Embora o manicômio represente uma pequena referência espacial, ele pode ser identificado como uma categoria universal, assim como podemos expandir as problemáticas que ocorrem nesse espaço, sem localização precisa, pois, como Saramago nos informa, "O mundo está todo aqui dentro" (SARAMAGO, 1995, p. 102). Esse tipo de construção espacial - parte-todo - causa no leitor uma sensação de angústia e mal-estar, pois nos são expostas as fraturas, as incoerências e as falências não somente de um espaço específico, mas que podem ser empregadas para todo o universo, onde quer que você esteja situado. Assim, Saramago fragiliza paulatinamente as simbologias e os conceitos que alicerçam a nossa civilização, pondo em xeque os pilares de um modelo secular que comanda a relação entre o homem e o espaço.

O branco representa um elemento significativo em Ensaio sobre a cegueira, surgindo já nas primeiras páginas do romance como uma alusão à cor da cegueira: "O cego ergueu as mãos diante dos olhos, moveu-as. Nada, é como se estivesse no meio de um nevoeiro, é como se tivesse caído num mar de leite, Mas a cegueira não é assim, disse o outro, a cegueira é negra, Pois eu vejo tudo branco" (SARAMAGO, 1995, p. 13). Ao longo do livro, o escritor subverte a dicotomia branco e preto, passando a caracterizar a epidemia da cegueira branca com referências paradoxais em que se misturam alusões à cor preta e a toda a simbologia que a mesma congrega, fazendo com que os significados do branco sejam esvaziados perante o caos insta urado pela doença, contradizendo a semântica da paz, luz e harmonia. A exemplo do que foi dito, podem ser citados os termos: "treva branca" (SARAMAGO, 1995, p. 28), "negra fatalidade" (SARAMAGO, 1995, p. 115) e "mal-branco" (SARAMAGO, 1995, p. 45, 125, 150).

A luz e a brancura são símbolos recorrentemente associados ao racionalismo e ao iluminismo, que demarcaram toda a formação do mundo ocidental e criaram o paradigma eurocêntrico como padrão de pensar e de viver. O ideal civilizacional europeu construiu-se a partir de um projeto de nação cuja estrutura se fundamenta na cultura, no progresso e na ciência, elementos que nortearam a criação da imagem do homem no mundo ocidental, servindo como estágios para se atingir a felicidade e a comodidade. A trilogia luz-razão-civilização encena 
capítulos da história do ocidentalismo no mundo, difundida e espalhada pelas mais diversas nações do globo.

Os símbolos do ocidentalismo sofrem sensíveis abalos ao se deparar, ficticia mente, com o mal da cegueira, que desestabiliza a ordenação, a força e a segurança de uma determinada cidade. Um dos exemplos de organização do espaço urbano que desponta na primeira página do romance é o sinal de trânsito, que se desorga niza diante do pânico do primeiro homem a cegar instantaneamente. Nesse instante, Saramago sugere a fragilidade e a insuficiência dos projetos ocidentais de nação por meio da descrição de um ordinário e confuso instante vivido no trânsito pelos motoristas e pelos transeuntes.

O sinal verde acendeu-se enfim, bruscamente os carros arrancaram, mas logo se notou que não tinham arrancado todos por igual. O primeiro da fila do meio está parado, deve haver ali um problema mecânico qualquer, [...] Alguns condutores já saltaram para a rua, dispostos a empurrar o automóvel empanado para onde não fique a estorvar o trânsito, batem furiosamente nos vidros fechados, o homem que está lá dentro vira a cabeça para eles, a um lado, a outro, vê-se que grita qualquer coisa, pelos movimentos da boca percebe-se que repete uma palavra, uma não, duas, assim é realmente, consoante se vai ficar a saber quando alguém, enfim, conseguir abrir uma porta, Estou cego.
[...] O semáforo já tinha mudado de cor, alguns transeuntes curiosos aproximavam-se do grupo, e os condutores lá de trás, que não sabiam o que estava a acontecer, protestavam contra o que julgavam ser um acidente de trânsito vulgar, farol partido, guarda-lamas amolgado, nada que justificasse a confusão, Chamem a polícia, gritavam, tirem dai essa lata. (SARAMAGO, 1995, p.11-12, grifo nosso)

Comumente tido como exemplo de ordenação, desenvolvimento e civilidade, o pequeno incidente no trânsito causa bastante transtorno, como se observa nas palavras em grifo que expressam agitação e discussão entre as pessoas. O fragmento mostra que, diante de uma pequena provocação, a estabilidade inicial transforma-se em caos urbano. A confusão no trânsito representa o índice de toda a provação por que passará a cidade, chegando à lastimável situação que a mulher do médico testemunha com as seguintes palavras: "O tempo está-se a acabar, a podridão alastra, as doenças encontram as portas abertas, a água esgota-se, a comida tornou-se veneno," (SARAMAGO, 1995, p. 283).

Como se pode perceber, o conceito de civilização é constantemente agredido pela cegueira branca, que traz à superfície tudo aquilo que o mundo civilizado teme e nega, ou seja, representa uma a meaça real aos seus princípios, 
comportamentos e ideologias. Consequentemente, os governos munem-se de estratégias extremamente agressivas, que são apoiadas pelo discurso falacioso de que o emprego da violência se justificaria em defesa do resgate da soberania nacional, a qual, por sua vez, sustenta e é sustentada pela manutenção dos princípios de ordem, de homogeneidade e de unidade.

Esses três princípios são mantidos através de um perigoso e bélico jogo de poder, que atua seja através da imposição de armas, de um discurso agressivo ou do poder econômico, impondo sempre por meio de muita violência, intolerância e desrespeito. Em Ensaio sobre a cegueira, vemos esse jogo de forças por meio da atuação do governo e do exército, que tentam manter o tempo todo a ordem e a harmonia, o escritor expõe uma forma bastante crítica de encarar os projetos do governo, como em: "As notícias não foram a nimadoras, corria o rumo de estar para breve a formação de um governo de unidade e salvação nacional” (SARAMAGO, 1995, p. 131).

Observa-se uma sensação de desânimo e descrédito acerca das notícias sobre a atuação do governo diante do problema da cegueira, pois há uma consciência de que o encarceramento não visa à cura dos cegos, mas a uma situação de autodestruição, a exemplo das péssimas condições de vida impostas ao grupo do manicômio, o que pode ser observado em: "O sargento ainda disse, Isto o melhor era deixá-los morrer à fome, morrendo o bicho acaba-se a peçonha" (SARAMAGO, 1995, p. 89). As interferências governa mentais são recebidas com cautela dada a situação já habitual de emprego da violência e da barbárie em nome da ordem em situações de conflito.

Além do exército, outras forças convergem para legitimar e fortalecer as ações do governo: a ciência, a cultura e a religião. Interessante observar que os três elementos lembrados se colocam no a mbiente social como agentes de emancipação do homem, devendo intervir e apoiar na relação do homem com o mundo. No caso da ciência, o romance expõe a impossibilidade de ação dessa força diante da experiência da cegueira, como sugere a passagem em que o governo reúne a comunidade científica de oftalmologistas e neurologistas para discutir tal problema, que resulta em um desastre completo:

O efeito conjugado da patente inutilidade dos debates e os casos de algumas cegueiras súbitas ocorridas em meio das sessões, com o orador a gritar, Estou cego, estou cego, levaram os jornais, a rádio e a televisão, quase todos, a deixarem de ocupar-se de tais iniciativas, exceptuando-se o discreto e a todos os títulos louvável comporta mento de certos órgãos de 
comunicação que, vivendo à custa de sensacionalismo de todo tipo, das graças e desgraças alheias, não estavam dispostos a perder nenhuma ocasião que aparecesse de relatar ao vivo com a dramaticidade que a situação justificava, a cegueira súbita, por exemplo, de um catedrático de oftalmologia. (SARAMAGO, 1995, p. 124)

O discurso da ciência impôs-se como a voz da verdade e, ironicamente, resulta em uma completa "inutilidade" quando requisitado para resolver situações extremas, especialmente quando a própria comunidade científica vive tal flagelo. O romance mostra a ineficácia do discurso científico em auxiliar em situações que fogem do domínio dos livros, os quais não preveem soluções para dilemas humanos como a cegueira.

Para pensar a questão cultural, podemos pegar o caso do escritor que tenta narrar os fatos vividos através da experiência dos outros, que prefere ficar em casa e ouvir as histórias a imergir no mundo, como mostra a seguinte passagem:

Gostaria que me falassem de como viveram na quarentena, Porquê, Sou escritor, Era preciso ter lá estado, Um escritor é como outra pessoa qualquer, não pode saber tudo nem pode viver tudo, tem de perguntar e imaginar, Um dia talvez the conte como foi aquilo, poderá depois escrever um livro, Estou a escrevê-lo, (SARAMAGO, 1995, p. 277, grifo nosso)

O excerto sugere o estado de alienação da litera tura, que pode ser a mpliado para o campo da arte, perante as questões humanas e as demandas de um tempo presente. A arte, no contexto da obra, apresenta registros de um certo afasta mento da vida real, de desengajamento social, estando alheia aos problemas que envolvem os homens. No caso do escritor em questão, como não vivenciou a situação, depende da experiência de outras pessoas, as quais, por terem vivido momentos traumáticos, precisam de um tempo para verbalizar o que passou ("Um dia talvez lhe conte"). Nesse sentido, a arte mostra duas vezes sua ausência, uma primeira quando não presencia o ocorrido e uma segunda quando não pode expressar o fato pelo olhar estético e crítico da arte no momento de maior necessidade, em que mínguam as relações humanas e, por conseguinte, em que a arte poderia atuar como um instrumento de representação e resistência.

Vale lembrar algumas palavras de Sa ramago que afirmam o compromisso do escritor com o presente: "Meu compromisso é com o meu tempo." (SARAMAGO, 2010, p. 347). O escritor cego, representado no romance português e de quem se comentava a nteriormente, contra ria esse princípio que versa uma responsabilidade social do 
artista com seu presente, atitude que resulta em sua falência para tratar de um horror real vivido por pessoas reais. Por outro lado, o velho da venda preta, personagem do Ensaio sobre a cegueira, dispõe dos três quesitos fundamentais - experiência, sabedoria e compromisso social - para exercer a função de narrador da cegueira de sorte que, como sujeito sábio e vivido - "És um filósofo" (SARAMAGO, 1995, p. 269) -, suas palavras merecem respeito e espectadores atentos, como mostra a passagem que diz:

Desta vez aos três e quatro em cada cama, de companhia, os cegos acomodaram-se o melhor que puderam, fizeram silêncio, e então o velho da venda preta contou o que sabia, o que vira com os seus próprios olhos enqua nto os tivera, o que ouvira dizer durante os poucos dias que decorreram entre o começo da epidemia e a sua própria cegueira. (SARAMAGO, 1995, p. 122)

Vive-se, ademais, uma falência dos órgãos propagadores de cultura, como museus, cinemas e teatros: "[... nunca houve tanto silêncio no mundo, os cinemas e os teatros só servem a quem ficou sem casa e já desistiu de a procurar, algumas salas de espetáculos, as maiores, tinham sido usadas para as quarentenas [...]" (SARAMAGO 1995, p. 232).
Quanto à religião, ela sucumbe ta mbém ao caos, as igrejas passam a ser simples dormitórios ou lugares de descanso "No outro lado da rua, um pouco adiante, estava uma igreja. Haveria gente lá dentro, como em toda parte, mas devia ser um bom sítio para descansar, pelo menos antiga mente tinha sido assim." (SARAMAGO, 1995, p. 299), onde mesmo os santos apresentam os olhos vendados. O discurso religioso não consegue aquietar os conflitos e as ansiedades da população, não responde aos problemas decorrentes da cegueira no plano individual ou social, não contribui para a boa convivência e bem-estar humanos e abandona a luta pela dignidade humana.

O romance desmonta aos poucos todas as bases que sedimentam o projeto de civilização ocidental, de modo que todos os sistemas que o sustentam sucumbem a uma espécie de caos, provando sua incapacidade de responder às inquietações e às reais necessidades dos homens. Todos os órgãos legitimadores da ordem e da unidade nacional perdem seu poder de atuação ao serem ta mbém vitimados pela cegueira, fato que mostra a dificuldade de sua atuação para gerenciar seus próprios dilemas, já que se evidencia um enorme abismo entre "falar sobre" e "viver" a situação.

Concomitantemente à falência desses órgãos, objetos funcionais e simbólicos que norteavam a vida do homem 
em sociedade sofrem o mesmo impacto. Existem na obra qua tro objetos que perdem sentido e função: o rádio, o relógio, o dinheiro e o mapa, cada qual exercendo, antes da cegueira coletiva, funções pontuais relacionadas à transmissão de informaç̧ões, à marcação do tempo, à movimentação financeira e à orientação e ordenação geográfica. A cegueira condena, aos poucos, cada um à inutilidade, como mostram os trechos: "Durante muito tempo o velho da venda preta manteve o ouvido pegado à caixa agora inerte, como se estivesse à espera do regresso da voz e da continuação do noticiário." (SARAMAGO, 1995, p. 150); "Estúpida de mim, não dei corda ao relógio, e continuou a chorar, inconsolável.” (SARAMAGO, 1995, p. 100); "[...] todo o sistema bancário se veio abaixo num sopro, como um castelo de cartas [...]" (SARAMAGO 1995, p. 255); “[...] aos cegos não lhes interessa saber onde está o oriente ou o ocidente, o norte ou o sul, o que eles querem é que as suas tateantes mãos lhes digam se vão no bom caminho [...]" (SARAMAGO, 1995, p. 272).

Esses elementos simbolizam importantes conquistas humanas que acompanharam os movimentos dos homens, os quais sofreram constantes aperfeiçoa mentos a fim de exercer uma função cada vez mais precisa e eficaz. Fazem parte de uma complexa engrenagem social que tem como impulso criador o desejo do domínio e do controle, a saber, um desejo de controlar o tempo, o espaço e a produção humana, sendo que, com este último, pretende-se incluir na palavra "produção" tanto as realizações financeiras quanto os movimentos culturais, políticos e históricos, lembrando a importância do rádio que, por muito tempo, foi utilizado como o único divulgador dos feitos humanos.

Os quatro objetos aludem significativa mente ao vínculo de dependência criado entre os homens, os bens e as tecnologias, produtos que os auxiliaram a controlar sua rotina e seus costumes. Nesse sentido, a perda dessas referências torna-os ainda mais cegos e desorientados, assim como o governo, representante maior dos Estadosnação, que, quando percebe a falência das bases que o regimentam, perde seu poder e função de atuar como líder e orga nizador.

Em resumo, tanto o homem quanto o governo vão à falência diante da inimaginável situação da cegueira coletiva. A sensação de mal-estar e abandono dá-se em relação à política pública e, em um grau de maior desconforto, em relação ao entendimento de nossa própria natureza, como se a imagem humana que se conhecesse surgisse disforme e apagada. 
3. CEGUEIRA, HUMANISMO, ANIMALIZAÇÃO

$O$ fato que torna a cegueira ainda mais assustadora reside na possibilidade de transmissão, situação que ocasiona um estado geral de medo - "O medo cega" (SARAMAGO, 1995, p. 131) - que corrompe a aparente tranquilidade. O medo desencadeia situações no romance que provam a vulnerabilidade humana, uma vez que açula reações instintivas que o aproximam da noção de animalidade, em seu sentido mais pejorativo. Vale lembrar que a civilização se constrói a partir da repressão dos instintos humanos, que representariam elementos perturbadores da razão e da ordem. Por essa razão, Freud a nalisa a civilização a partir da instabilidade entre o bem e o mal, duas faces que estão em embate constante e se revezam muitas vezes no meio social. Em Ensaio sobre a cegueira, os personagens encarcerados no manicômio vivencia $m$ um estado de civilidade perturbado pela fome e pelo medo, que são apontados como elementos causadores do caos e da barbárie, como vemos em: "Se não nos organizarmos a sério, mandarão a fome e o medo, já é uma vergonha que não tenhamos ido com eles enterrar os mortos," (SARAMAGO, 1995, p. 96).

Viver impulsionado pelo medo e pela fome desencadeia uma série de ações de luta pela sobrevivência, estimulando o uso da força física em detrimento das ações habituais do homem civilizado e racional. O romance sugere esse embate ao mostrar a aproximação do leite e do sangue, que metaforicamente antecederá todo o conflito huma no gerado dentro do manicômio e, posteriormente, por toda a cidade.

Mas as caixas da comida, ali expostas, atraíam os olhos irresistivelmente, são deste calibre as razões do estômago, não atendem a nada, mesmo quando é para seu bem. De uma das caixas derramava-se um líquido branco que lentamente se ia aproximando da toalha de sangue, por todos os visos devia ser leite, é uma cor que não enga na. (SARAMAGO, 1995, p. 91)

O sangue derramado, como mostra o trecho acima, anuncia uma das inúmeras mortes que ocorrerão durante a cegueira e expressa momentos de dor e sofrimento que estariam por vir. Interessante ver que, conforme sugere a passagem previamente transcrita, a brancura do leite não exprime a sua simbologia usual de paz e tranquilidade, antecede, pelo contrário, momentos vindouros de lutas pelo alimento escasso. O leite simbolicamente indicia situações em que o alimento será objeto de disputa e levará a conflitos violentos, sendo utilizado como elemento de troca, para obter vantagens, primeiramente, financeiras e, depois de se esgotarem os bens materiais, favores sexuais. A luta pela comida isolará cada vez mais 
os homens, que apresentará duas soluções distintas, ou se organizar em pequenos grupos ou viver sozinhos.

Eles dizem que isso acabou a partir de hoje quem quiser comer terá de pagar. Os protestos saltaram de todos os lados na camarata, Não pode ser, Tirarem-nos a nossa comida, Cambada de gatunos, Uma vergonha, cegos contra cegos, nunca espere ter de viver para ver uma coisa destas, (SARAMAGO, 1995, p. 138)

A experiência da cegueira obriga os homens a vivenciarem dois tipos de comportamentos distintos. Por um lado, tem-se o grupo de huma nos que desenvolveu seus instintos agressivos e passou a viver o conflito entre o eu e o outro, de modo que o isola mento e a cegueira o obrigaram a desenvolver comporta mentos a nimalescos, como sugere a passagem: "Estes cegos, se não lhes acudirmos, não tardarão a transformar-se em a nimais, pior ainda, em a nimais cegos" (SARAMAGO, 1995, p. 134). Por outro lado, há pequenos grupos que desenvolveram outras habilidades, aprendendo a viver em comunhão, a compartilhar, a conviver com o outro, como vemos em:

Ajudem-me, disse a mulher do médico quando as viu, Como, se não vemos, perguntou a mulher do primeiro cego, Tirem

a roupa que têm vestida, quanta menos tivermos de secar depois, melhor, Mas nós não vemos, repetiu a mulher do primeiro cego, Tanto faz, disse a rapariga dos óculos escuros, faremos o que pudermos, E eu acabarei depois, disse a mulher do médico, limparei o que ainda tiver ficado sujo, e agora ao trabalho, vamos, somos a única mulher com dois olhos e seis mãos que há no mundo. (SARAMAGO, 1995, p. 266)

Tomemos o primeiro caso para reflexão. No romance, as pessoas transgridem as normas de comporta mento que tentam separar o homem dos a nimais, a cultura da natureza e dos instintos. Vemos que as fronteiras que nos separam desse outro universo são bastante tênues, de modo que nossos comportamentos instintivos reprimidos podem ser assanhados diante de certos estímulos emergenciais. Sa ra mago enumera, em vários momentos da na rrativa, situações em que o comporta mento humano se equipara ao de um a nimal, de modo que é comum encontrar trechos como o que se segue:

Toparam-se a meio caminho, os dedos com os dedos, como duas formigas que deveriam reconhecer-se pelos manejos das antenas, não será assim neste caso, o médico pediu licença, com as mãos tenteou a cara do velho, encontrou rapidamente a venda, Não há dúvida, era o último que nos faltava aqui, o paciente da venda preta, exclamou, (SARAMAGO, 1995, p. 120) 
No entanto, esse recurso narrativo não deve ser confundido com os antigos métodos naturalistas de escrita, que utilizavam os animais no intuito de depreciar as atitudes humanas. Saramago, portanto, não utiliza a ideia do "tornar-se a nimal" para julgar seus personagens, mas especialmente para referendar questões acerca dos limites do entendimento da palavra homem, rompendo com estruturas simplistas que o reduzem ao cultural e ao racional.

Podemos resgatar para essa reflexão o livro de Derrida $O$ animal que logo sou, que, assim como a obra do escritor português, transgride a lógica ocidental. A frase de herança iluminista "Penso, logo existo", considerada o grande mote da civilização ocidental, é questionada já no título da obra, acenando para o trabalho de desconstrução da lógica racionalista moderna. Essa frase conclusiva expressa o caráter racionalista da filosofia moderna que destina ao homem o lugar da fala e da razão. Nesse sentido, a afirmativa exclui e reprime todos os outros aspectos que dizem respeito à ordem da natureza, das paixões, dos instintos, das crenças, enfim, todo tipo de manifestação e realização que se afaste da lucidez, da iluminação, do científico.

Derrida mostra a fragilidade desse pensamento logocêntrico ao afirmar: "Acontece que existe entre a palavra 'eu' e a palavra 'animal', todo tipo de cruzamentos significativos. [...] Mas entre essa relação a si (este Si, esta ipseidade) e o eu do 'eu penso' existe, parece um abismo" (DERRIDA, 2002, p. 90-91). O teórico nos mostra que entre o eu (homem) e o a nimal e entre o eu (mesmo) e o outro (alteridade) estabelecem-se diversos cruzamentos, de modo que essas categorias mais se corrompem do que se excluem. A questão derridia na não parte da homogeneização homem e animal, eu e outro, mas conjectura uma rasura da perspectiva logocêntrica a partir do reconhecimento de "uma multiplicidade heterogênea de viventes” (DERRIDA, 2002, p. 60), respeitando as diversas individualidades e histórias envolvidas, de modo que cada um "participaria de sua própria história e em seu próprio nome”.

A representação do cão das lágrimas consegue encenar esse imbricado existencial em que se sobrepõem, se enlaçam, se indefinem a condição humana e a condição animal. Como ilustração, tem-se o momento em que o cão faz sua própria escolha ao se juntar ao grupo dos sete cegos e passa, então, a traçar sua própria história dentro desse grupo e a participar efetivamente da vida social desses humanos. Saramago, ao narrar seu encontro com a mulher do médico, mostra uma enorme sensibilidade em relação ao animal, que passa a fazer parte 
da narrativa, pois, embora desprovido de linguagem humana, o cão expressa um tipo de comunicação bastante peculiar.

Não há dúvida, está perdida. Deu uma volta, deu outra, já não reconhece nem as ruas nem os nomes delas, então, desesperada deixou-se cair no chão sujíssimo, empapado de la ma negra e, vazia de forças, de todas as forças, desatou a chorar. Os cães rodearam-na, farejam os sacos, mas sem convicção, como se já lhes tivesse passado a hora de comer, um deles lambe-lhe a cara, talvez desde pequeno tinha sido habituado a enxugar prantos. A mulher toca-lhe na cabeça, passa-lhe a mão pelo lombo encharcado, e o resto das lágrimas chora-as abraçada a ele. [...] Tem, porém a palavra comida poderes mágicos, mormente quando o apetite aperta, até o cão das lágrimas, que não conhece linguagem, se pôs a abanar o rabo, o instintivo movimento fê-lo recordar-se que ainda não tinha feito aquilo a que estão obrigados os cães molhados, sacudirem-se com violência, respingando quanto estiver ao redor, neles é fácil, trazem a pele como se fosse um casaco. (SARAMAGO, 1995, p. 226-227)

A aproximação do cão das lágrimas com o mundo dos homens desperta-lhe sentimentos humanos, chegando inclusive a sofrer como os homens. Contudo, não estamos tratando de um processo de antropomorfização, em cuja representação o homem impõe sua condição huma na como forma de projetar-se e, consequentemente, depreciar o a nimal e seus comportamentos ditos animalescos. O comentá rio crítico de Sara mago sobre o procedimento do símile, muito usado na literatura para comparar o não-huma no ao humano, elucidará o que está sendo posto em questão: "O símile é magnífico, embora tenhamos de censurar nele a cedência às tentações do antropomorfismo, que tudo vê e tudo julga em relação obrigatória com o homem, como se, de facto, a natureza não tivesse mais que fazer que pensar em nós" (SARAMAGO, s/d, p. 304). O escritor adverte sobre o perigoso jogo dessas aproximações que recorrem à técnica do a ntropomorfismo, pois se lhe atribuem ca racterísticas humanas no intuito de engrandecer sua própria condição, o que reflete uma relação hierárquica entre objeto representado e objeto referenciado.

Nas obras de Saramago, as representações dos a nimais transgridem essas hierarquias que separam em lados opostos seres inferiores e superiores, a nimais e homens, irracional e racional. Em muitas passagens, o escritor revela uma dificuldade do homem em compreender a complexidade do mundo dos a nimais, incluindo aî uma dificuldade do próprio escritor em representar um mundo que não se expressa pela linguagem humana. $\mathrm{A}$ 
não-linguagem verbal do animal não o impossibilita de expressar sensações de sofrimento e alegria, como vemos na passagem abaixo:

Entalado entre dois carros, o corpo de um homem apodrece. A mulher do médico desvia os olhos. O cão das lágrimas aproxima-se, mas a morte intimida-o, ainda dá dois passos, de súbito o pêlo encrespou-lhe, um uivo lacerante saiu-lhe da garganta, o mal deste cão foi ter-se chegado tanto aos humanos, vai acabar por sofrer como eles. (SARAMAGO, 1995, p. 295)

Ao representá-lo dessa forma, Saramago provoca o leitor a questionar sua humanidade e a animalidade desse outro, quebrando fronteiras que se supunham rígidas, mas que, ao serem postas à prova, esfacela m-se mostrando sua instabilidade. Diante desse a nimal que desnuda o homem, conseguimos nos ver através dos olhos desse outro, que Derrida denomina de outro absoluto, de modo que a narrativa passada através dos olhos do cão das lágrimas traz uma outra resposta - a de um vivente que se apieda e que sofre pelo sentimento do outro, a qual desautoriza a noção da passividade e irracionalidade.

Derrida termina o texto questionando sua própria condição humana: "Mas eu, quem sou eu? / [

..)" (DERRIDA, 2002, p. 92), condição essa criada pelo próprio homem para viver em sociedade, mas que mostra sua insuficiência em explicar a complexidade e heterogeneidade humana. O homem aprendeu a afirmar-se por meio da negação do outro e pela negação do outro em mim, pela negação de todo comportamento que, a seus olhos, não seja considerado "civilizado". Derrida mostra que, para se tornar sujeito, o homem tende a assujeitar o outro, impondo uma visão a rroga nte que subjuga e rotula o outro como bárbaro, inculto e não-civilizado. Ao questionar sua condição, Derrida desestabiliza a noção vigente de humano, rasura os conceitos dicotômicos que separam o homem do animal. O filósofo testa sua própria compreensão acerca do animal, de modo a lançar uma série de questiona mentos: "O a nimal em geral, o que é? O que isso quer dizer? Quem é? 'Isto' corresponde a quê? A quem? Quem responde a quem? Quem responde ao nome comum, genérico e singular do que eles chamam assim tranqüilamente 'o animal'? Quem é que responde?" (DERRIDA, 2002, p. 92).

Interessante observar o efeito retórico que esse montante de questões lançadas por Derrida causa no leitor, provocando uma sensação de descomodidade. Efeito similar ocorre com o poema de Drummond "Especulações em torno da palavra homem”, só modificando o objeto do 
questionamento, como o próprio título indica. Embora as questões de Derrida e Drummond referendem distintas subjetividades, é o homem e sua humanidade que estão sendo desnudados, pervertidos:

\section{Mas que coisa é homem,}

que há sob o nome

uma geografia?

um ser metafísico?

uma fábula sem

signo que a desmonte?

$[\ldots]$

Que milagre é o homem?

Que sonho, que sombra?

Mas existe o homem?

(DRUMMOND, 1999, p. 214-219)

Através do texto de Derrida e de Drummond, percebe-se que as certezas acerca do entendimento de homem e a nimal são abaladas, certezas essas que se torna m especulações, e as afirmativas cedem lugar às interrogações "Mas existe o homem?". Derrida transita dos pronomes "o que" e "isto" para "quem", termos que, na linguagem humana, são utilizados para representar distinta mente a nimais ou coisas ina nimadas e pessoas, em outras palavras, ta transição inverte a lógica da representação do animal como coisa, como objeto. Já o poema de Drummond sugere essa mesma rasura ao dizer "que coisa é homem", associação (coisa-homem) um tanto paradoxal, tendo em vista o valor semântico de "coisa" como algo genérico, disforme e, portanto, vazio de identidade e sentido humano. Se, por um lado, transparece uma tentativa de a firmação de uma identidade, de uma voz, por outro, há um esvaziamento do homem-totalidade, ou seja, do homem como princípio e fim de todas as coisas, como o centro de referência que condiciona os outros viventes a ocuparem uma posição de sub-existência.

Esse homem-totalidade, quando se vê diante da presença do outro, sente-se a meaçado por sua aparição, de modo que, por intermédio de uma reação meio que instintiva, reage no intuito de suprimir a diferença. Entretanto, a alteridade reprimida não desaparece, mas sobrevive como um fantasma, como um rastro perturbador, torna ndo-se tão nociva qua nto uma aparição física. $O$ reprimido não significa ausência absoluta, mas uma presença contínua, um "Estar depois, estar junto, estar perto de, eis, aparentemente, diferentes modalidades do estar, em verdade do estar-com." (DERRIDA, 2002, p. 27), que é, ou espera-se que seja, controlado o tempo todo. A alteridade reprimida não é passiva e está sempre em tensão e em movimento, por isso compreendida como 
ameaça ao homem-totalidade. Derrida joga semanticamente com esse espaço de tensão em:

Elas dizem em todo caso de uma certa ordem no estar-apertado ["l'étre-serré"] (o que nos indica a etimologia pressu, da qua derivariam as palavras perto ["près"], junto ["auprès"], depois ou atrás ["après"]), o estar-apressado, o estar-com enquanto estritamente fixado, ligado, acorrentado, o estar-sob-pressão, comprimido, imprimido, reprimido, estreitado conforme o estrangulamento mais ou menos forte do que permanece sempre premente. (DERRIDA, 2002, p. 27-28)

Pela citação de Derrida, é notória a sensação de que o elemento reprimido está ali, bem perto, ligado, conectado, a contragosto de forças hegemônicas, a que se acrescenta uma segunda leitura que se apoia na escolha terminológica de estar preso, reprimido, acorrentado, para resgatar uma outra impressão derridiana, a qual acena para ações rotineiras de cerceamento e repressão violenta da alteridade. Se se investiga $\mathrm{m}$ as distintas expressões da alteridade em processos aproximativos, visualizar-se-á discursivamente o testemunho da apreensão, haja vista que a relação eu e outro aciona um pesado legado de desconfianças, dada a frequência de situações acompanhadas de ímpetos genocidas, destrutivos e supressórios.

\section{HOMEM, HUMANISMO, HUMANIZAÇÃO}

Da leitura de Ensaio sobre a cegueira ressoa uma voz crítica que la menta a desumanização do homem, ao mesmo tempo em que se expressa um chamado para que valores e condições humanas não abandonem a pauta do dia José Saramago reivindica constantemente em seus trabalhos uma "humanização da humanidade", de modo a representar artisticamente o desvanecimento do sentido de huma nismo e as perdas que esse fato visivelmente acarreta e pode ainda acarretar. Em As palavras de Saramago, o escritor ratifica esse chamado dizendo: "Continuo pedindo a humanização da humanidade. Isso morreu? Se morreu é uma autêntica tragédia" (SARAMAGO, 2010, p. 147). Ensaio sobre a cegueira, portanto, assume uma postura menos lamuriosa e mais provocativa, afetando diretamente o homem e a desuma nidade do homem, seja ela representada pela desassistência e descaso governamental, pelo desengaja mento científico e cultural, pelo descoletivismo, pela indiferença, em suma, pela desumanidade generalizada que autoriza a afirmação cruel de que: "É dessa massa que nós somos feitos, metade de indiferença e metade de ruindade” (SARAMAGO, 1995, p. 40).

Martin Heidegger publica, em 1947, Sobre o humanismo, um texto fulcral para a discussão do humanismo, produzido a partir do questiona mento de um crítico leitor que 
levantou a seguinte pergunta: "Comment redonner un sens au mot 'Humanisme?'” (De que maneira se pode restituir um sentido à palavra 'humanismo'?). Ma is que uma simples resposta, a pergunta desperta no filósofo duas intrigantes questões: "Sua pergunta não pressupõe somente que o Senhor pretende conservar a palavra 'huma nismo'. Ela implica ta mbém o reconhecimento que essa palavra perdeu o seu sentido" (HEIDEGGER, 1967, p. 71-72). A fala de Heidegger reforça a noção de esgarça mento do termo, o qual perde sentido e valor diante de uma realidade social desfavorável e aliciadora da humanidade do homem. Por outro lado, Heidegger mostra que o ato de questionar o humanismo já representa em si um desejo em mantê-lo, o que prova o reconhecimento de seu valor no meio social, especialmente em situações conflituosas e extremadas.

Esse esvaziamento do termo indicia uma necessidade de redimensionar os valores humanos. Os novos humanistas, ao proporem falar sobre o humanismo, acabam falando contra o humanismo e a favor de um humanismo, considera ndo que "[...] é possível ser crítico do humanismo em nome do huma nismo [...]." (SAID, 2004, p. 29). Esse huma nismo que está sendo buscado não é o humanismo pura mente ideológico, metafísico ou transcendental, é um humanismo do homem e para o homem, portanto, sua reformulação resulta de uma reivindicação do próprio mundo, das experiências e necessidades humanas. Esse humanismo deve desnudar as relações de poder, subverter a herança logocêntrica, ler e reler criticamente a história das relações humanas, interferir em nossa forma de ver e recepcionar o outro, substituindo o legado da violência e da desconfiança. Ele deve expressar o ser em sua diversidade e complexidade, contemplando os homens, no plural, sempre os pensando em relação com o mundo, conforme lembra Heidegger: "[...] o homem nunca é homem, aquém do mundo [...]" (HEIDEGGER, 1967, p. 79).

Heidegger sugere analisar e buscar a "humanitas" do homem, ou seja, tornar o homem humano: "Pensar a Verdade do Ser significa igualmente: pensar a humanitas do homo humanus. Trata-se de pôr a humanitas a serviço da Verdade do Ser, mas sem o huma nismo em sentido metafísico" (HEIDEGGER, 1967, p. 83). Em latim, o termo humanitas significava humanidade, a natureza humana, a espécie humana, o espírito humano, sentimentos próprios do homem, benevolência, bondade, instrução, educação, cultura, cultura do espírito, polidez, cortesia, urbanidade, graça. Vê-se que a etimologia do termo congregava valores humanos que focavam o homem como ser social, cujos valores morais, a fetivos e culturais 
indicariam qualidades fundamenta is para um relacionamento saudável entre indivíduos.

O humanismo desempenha o duplo papel de representar os valores humanos do homem e de trabalhar em defesa do seu bem-estar, orquestrando um tipo de formação social que prevê uma pré-disposição ao entendimento e à cooperação. Valendo-nos da metáfora da cegueira branca, a cegueira, em suas mais diversas manifestações no nosso mundo pós-moderno, embarreira as práticas humanistas e humanitárias, uma vez que dissemina indiferença, isola mento e desengajamento. Se, por um lado, o humanismo estimula conhecimento e participação, por outro, a cegueira produz ignorância e alienação. $\mathrm{O}$ humanismo e os valores humanistas carregam o potencial de descortinar as barreiras que são cotidianamente erguidas na aproximação do eu com o outro, em que o olhar armado bloqueia avanços no processo comunicativo e relacional.

Uma última citação do Ensaio sobre a cegueira tem o potencial de resposta a toda a discussão levantada a té aqui sobre o lugar do humanismo e da huma nização em tempos tão adversos, ao trazer um pequeno diálogo que diz: "Engano teu, as imagens vêem com os olhos que as vêem, só agora a cegueira é para todos. Tu continuas a ver, Cada vez irei vendo menos, mesmo que não perca a vista tornar-me-ei mais e mais cega cada dia porque não terei quem me veja." (SARAMAGO, 1995, p. 302). A resposta da Mulher do médico, única personagem que resiste à cegueira, é emblemática para pensar-se a aplicabilidade do humanismo em contextos hostis e desumanos de cegueira do homem, sua reposta traz como contraponto ao cenário de brutalidade e violência a necessidade de estar entre os homens, diante dos homens, de ver e ver-se vista pelos olhos do outro. Seguindo essa leitura, no romance, a cegueira coletiva representaria um tipo de isolamento que torna o sujeito dupla mente cego, no sentido de não poder ver e no sentido de não poder ver-se nos olhos do outro.

Talvez muito mais do que responder à pergunta "Há espaço para o humanismo hoje?” seria mais produtivo levantar o questionamento "Que tipo de humanismo podemos produzir hoje?”. Esta última, mais assertiva, pressupõe por si uma agenda de pré-disposição a. Para tanto, a réplica da mulher do médico à intervenção "Tu continuas a ver" mais uma vez se mostra oportuna. Seu discurso exprime genuína humildade, continuando a ver em terra de cegos, em vez de assumir uma posição de projeção sobre a condição vulnerável do outro, lastima não poder ser vista e ver-se vista, como a reconhecer nisso a sua fraqueza, localizando na cegueira do outro o comprometimento de seu sentido de visão e a consequente falência da condição humana. 
À luz dessas últimas considerações, retomamos o questiona mento inicial: "Mas que tipo de humanismo podemos produzir hoje?”. Da representação da fala da Mulher do médico, pode-se extrair um encaminhamento de resposta. Homem, huma nidade e humildade: termos que, etimologicamente, apresenta m uma raiz em comum, humus, que carrega o sentido orgânico de terra. Do latim, humilitas e humilis, na língua portuguesa, humildade e humilde, expressam a ideia de pouca elevação, baixa estatura, que está no chão, de algo humilde, modesto. Em resumo, aproximando as heranças etimológicas do termo humildade, podemos associá-lo àquilo que fala do chão, que fala de baixo, sem projetar-se sobre e acima. Humus, com efeito, acende um legado imprescindível para as práticas e condições humanas e humanitárias, que parece denotar o sentido de estar ligado a terra, ao cuidado com a vida, sem a a mbição de alçar grandes voos, de ser maior que. A resposta ao chamado humanista em tempos como o que vivemos parece apostar em pequenas mostras de humildade, como o ato genuíno da mulher do médico, em que um gesto pontual pôde suavizar um contexto maior de provas de desumanidades.

\section{REFERÊNCIAS}

ANDRADE, C. D. Antologia poética. Rio de Janeiro: Record, 1999
FREUD, S. O mal-estar na civilização. Trad. José Octávio de Aguiar Abreu. Rio de Janeiro: Imago, 1997.

DERRIDA, J. O animal que logo sou. Trad. Fábio Landa. São Paulo: Editora UNESP, 2002

HEIDEGGER, M. Sobre o humanismo. Trad. Emmanuel Carneiro Leão. Rio de Janeiro, Tempo Brasileiro, 1967.

SAID, E. Humanismo e crítica democrática. Trad. Rosaura Eichenberg. São Paulo: Companhia das Letras, 2007.

SARAMAGO, J. Ensaio sobre a cegueira. São Paulo:

Companhia das Letras: 1995.

A jangada de pedra. Rio de Janeiro: Editora Record, s.d.

As palavras de Saramago: catálogo de reflexões pessoais, histórias e políticas. Fernando Gómez Aguilera (sel. e org.). São Paulo: Companhia das Letras, 2010.

Recebido em: 25-06-2020 Aceito em: 22-03-2021. 